\title{
Using Dartmoor ponies in conservation grazing to reduce Molinia caerulea dominance and encourage germination of Calluna vulgaris in heathland vegetation on Dartmoor, UK
}

\author{
Paul H. Lunt ${ }^{1 *}$, Jakob L. Leigh ${ }^{1}$, Samantha A. McNeil ${ }^{1} \&$ Malcolm J. Gibb ${ }^{2}$
}

https://doi.org/10.52201/CEJ18SVSR7750

\author{
1 University of Plymouth, School of Geography, Earth and Environmental Science, Portland Square, Drake Circus, Plymouth, \\ Devon PL4 8AA, UK \\ ${ }^{2}$ Retired, formerly of the Institute of Grassland and Environmental Research, North Wyke, Devon EX20 2SB
}

\section{SUMMARY}

The increasing dominance of purple moor-grass Molinia caerulea in heathland ecosystems in the UK is of growing concern due to its detrimental impact on plant and animal diversity on sites of nature conservation interest. The use of free-ranging ponies to reduce Molinia dominance was investigated from 2017 to 2019 within a 425 ha site on Dartmoor, UK. Salt blocks were used to attract the ponies to a Molinia-dominated area of heath within the site, away from their previously-preferred grazing areas. The impact of pony grazing was assessed by measurements of vegetation structure and plant species composition. The increased presence of ponies in the vicinity of the salt blocks increased the percentage occurrence of bare ground, reduced sward surface height, reduced percentage occurrence of Molina and increased the germination of heather Calluna vulgaris seedlings. The conclusions of this research are that salt blocks can be used to attract ponies to graze targeted areas of Molinia-dominated heathland. Through their grazing and trampling, ponies can reduce the dominance of Molinia, leading to an increase in the germination and establishment of heather seedlings.

\section{BACKGROUND}

Heather-dominated upland heaths are of international importance for nature conservation, supporting a range of specialist invertebrate and bird species (Mitchell et al. 2008). Upland heathland, a Priority Habitat listed in Section 41 of the NERC Act 2006 (JNCC 2008), has been in decline since the 1950s in the UK and Europe due in part to increased nitrogen deposition and rainfall (Sala et al. 2000, Murphy et al. 2019), leading to an increase in the dominance of Molinia (Milligan et al. 2004) - a growing concern for nature conservation and habitat management (Chambers et al. 1999, Mitchell et al. 2008).

Molinia is a perennial, tussock-forming grass species, which prevents the regeneration of heather. Growth commences in early spring with rapidly growing, young leaves, which, by late spring, outcompete heather seedlings for light and space. By mid-July, ungrazed, senescent Molinia leaves become coarse and, during autumn and winter, form a thick raffia-like mat, which smothers other heathland plants. Cutting or managed burning regimes alongside livestock grazing are typically used to maintain upland dry heathland (Legg et al. 1992, Mitchell et al. 2008, Critchley et al. 2013). Any management to reduce Molinia should be considerate of the potential to release $\mathrm{CO}_{2}$ from valuable carbon stores on peaty soils and the appropriateness and availability of livestock for grazing (Marrs et al. 2004). Studies have also shown that overgrazing and burning can lead to loss of heather and create Molinia-dominated areas with lower structural diversity (Ross et al. 2003, Yallop et al. 2006).

\footnotetext{
*corresponding author email: paul.lunt@plymouth.ac.uk
}

Much of the literature surrounding upland grazing focuses on sheep (Marrs et al. 2004) and cattle (Mitchell et al. 2008). Of the 15 studies from the UK, reviewed in Conservation Evidence (Dicks et al. 2020), nine found that appropriate management can help to maintain the conservation value of upland heath or moorland. Four studies found that a reduction in grazing increased heather cover. One study on heathland in northern Spain (Aldezabal et al. 2013), found that increasing the number of ponies present at the site reduced grass height in most cases. Cattle and ponies both consume grasses in preference to dwarf shrubs (Celaya et al. 2011). However, ponies have a greater preference for Molinia and a lower preference for heather in comparison to sheep and cattle (Celaya et al. 2011, Fraser et al. 2019). A study by Putman et al. (1987) in the New Forest, found that Molinia contributed on average $20 \%$ of summer diet in ponies. López López et al. (2019) suggested that equids are less able to tolerate the tannins in heather than are ruminants, such as sheep and cattle.

Equines require salt, specifically sodium chloride, in their diet ( $\sim 50 \mathrm{~g}$ daily), as it is an essential metabolic requirement (Kaspari 2020). Sodium chloride occurs in low concentrations in plants. Ponies, in common with other herbivores, will seek mineral sources, such as salt deposits, to supplement their intake, particularly when grazing mineral poor pasture. There were two aims to this study: 1) examine whether salt blocks could be used to attract Dartmoor ponies to preferentially graze in selected Molinia-dominated areas, and 2) determine whether increased grazing and trampling of Molinia by ponies leads to an increase in germination and establishment of heather seedlings. 


\section{Study Site}

The Bellever Forest site is located near Postbridge, within the Dartmoor National Park, UK (Figure 1). The total area of 425 ha is surrounded by stock-proof fencing, but with public access, and comprises 88 ha of a moorland Site of Special Scientific Interest (SSSI) and 337 ha of Sitka spruce Picea sitchensis plantation. The study was confined to Lakehead Hill $\left(50^{\circ} 34^{\prime} 56^{\prime \prime} \mathrm{N}, 3^{\circ} 55^{\prime} 03^{\prime \prime} \mathrm{W}\right)$, an area of about 8 ha of moorland, comprising a narrow strip of land between spruce plantations (Figure 1) dominated by dense stands of Molinia tussocks with locally frequent, senescing mature heather plants. The soils on the hill consist of a mixture of shallow peat under $50 \mathrm{~cm}$ deep with occasional mineral exposure. The site has been leased by the Dartmoor Pony Heritage Trust since 2009 and, until 2017, was stocked year-round with 26 registered Dartmoor ponies. In 2018 and 2019 the number of ponies was reduced to 19 and 15, respectively. No cattle or sheep were present on the site. Prior to commencement of the study in 2017, anecdotal evidence provided by trust volunteer staff was that the ponies were rarely observed grazing on Lakehead Hill. The ponies' preferred grazing areas were on short turf vegetation, primarily $500 \mathrm{~m}$ to the south. The primary objective of the study, therefore, was to examine whether the ponies could be attracted to graze on the Moliniadominated area of Lakehead Hill.

\section{ACTION}

\section{Experimental Design}

An unreplicated, before-and-after, controlled site comparison was carried out in 2017-2019. In March 2017, 10 circular plots (24 m diameter) were randomly selected within defined Moliniadominated areas of Lakehead Hill. All plots were identified with centrally-located marker posts. Five plots were randomly assigned to receive a single salt block (Himalayan rock salt, 20 × $20 \times 20 \mathrm{~cm}$ ), attached to the marker post (treatment Salt), whilst the five remaining plots had no salt blocks (treatment No-salt). Following extreme trampling around the Salt posts in the first year, two adjustments were made to the experiment in the following two years. In order to avoid further trampling damage to vegetation and the underlying soil around the salt block posts, from March to September of 2018-2019, a salt block was attached to the central marker post of a single Salt plot. A replacement salt block was provided approximately every 3 weeks, randomly allocated to one of the five Salt plots.

In 2019, three further plots, within the Moliniadominated area, were added (Figure 1) as control plots (Control) in order to assess the condition of the vegetation away from the Salt and No-salt plots.

\section{Sampling methods}

In March 2017, before the installation of salt blocks, the following baseline data were collected on all 10 plots:

(i) Sward surface height was measured at $1 \mathrm{~m}$ intervals on a transect $1-10 \mathrm{~m}$ from the plot centres, using a sward stick. Each transect was replicated 16 times on secondary inter-cardinal bearings (i.e. N,

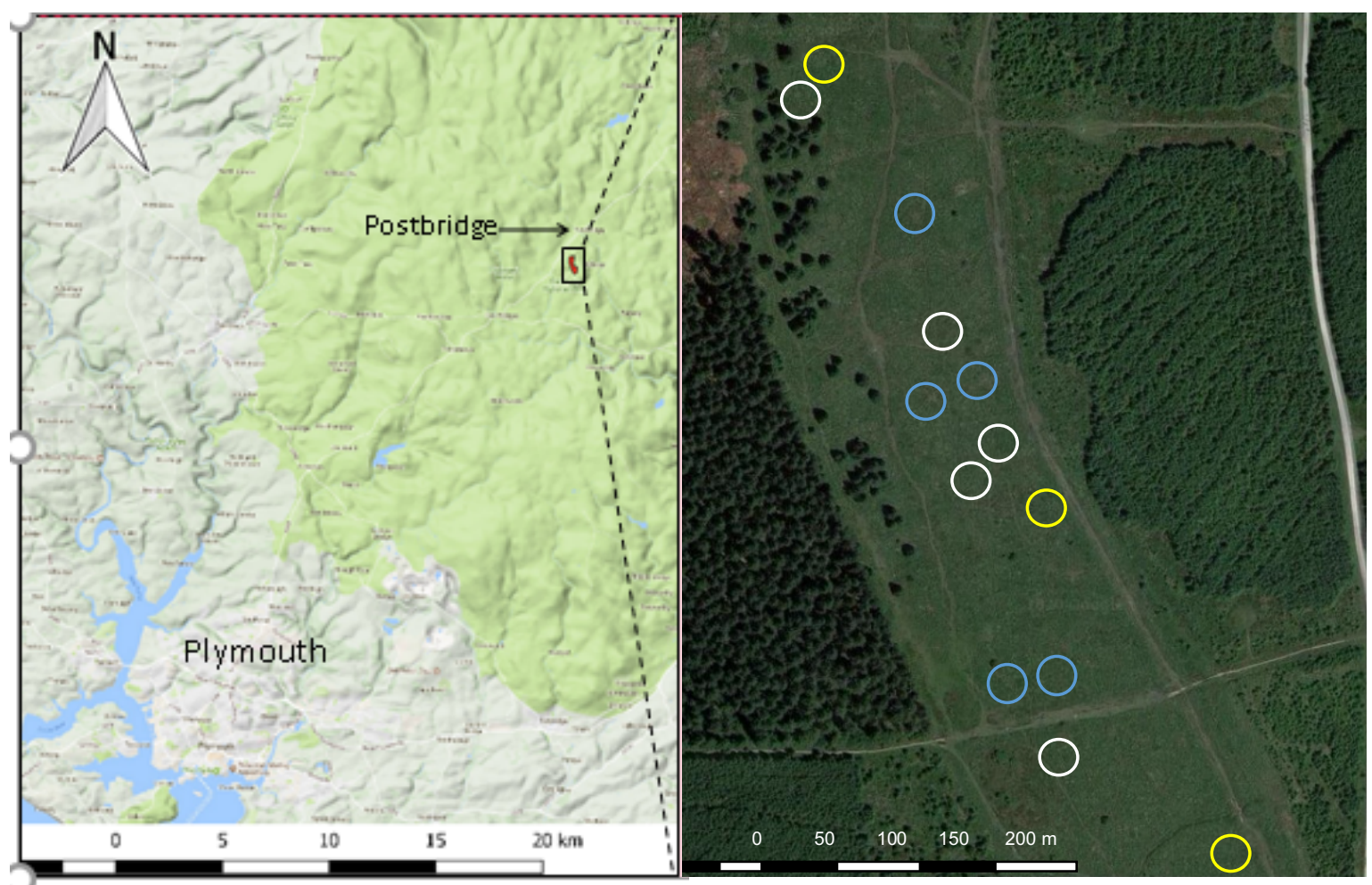

Figure 1. Aerial image of the Lakehead study site $\left(50^{\circ} 34^{\prime} 56^{\prime} \mathrm{N}, 3^{\circ} 55^{\prime} 03^{\prime \prime} \mathrm{W}\right)$, with circles superimposed to show $12 \mathrm{~m}$ radius salt plots (blue), control plots with posts (white) and unmarked control plots (yellow). (Google Maps, 2019); (QGIS, 2019). 
NNE, NE etc.) from the centres of plots (192 measurements/plot).

(ii) Herbage mass was derived using a doublesample technique to establish a relationship between sward height, measured with a rising-plate metre (Ashgrove Co), and herbage dry matter harvested to ground level within a $30.5 \mathrm{~cm}$ diameter frame. Plate height measurements were then taken at intervals as for the sward height measurements.

In June 2019, the following measurements were made in all 13 plots:

(i) Sward height was measured at $1 \mathrm{~m}$ intervals, on transects $1-12 \mathrm{~m}$ from the plot centres as described above.

(ii) Number of heather seedlings, \% Molinia cover and $\%$ bare ground was recorded within each of the six $0.5 \mathrm{~m} \times 0.5 \mathrm{~m}$ gridded quadrats (individual counts made within 100 cells) at distances of $1,2,3$, $4,5,7,10$ and $12 \mathrm{~m}$ from the plot centre on random compass bearings (i.e. 48 quadrats/plot).

(iii) Number and height of Molinia tussocks were also recorded in each of the above $0.5 \mathrm{~m} \times 0.5 \mathrm{~m}$ quadrats.

(iv) A condition assessment of mature heather plants was carried out, in which all individual plants within Salt and No-salt plots were categorised as either healthy with green leaves or in poor condition (greater than $50 \%$ of branches senescent with sparse and discoloured leaves).

\section{Data Analysis}

Data were analysed using Microsoft Excel. Oneway ANOVA was used to test for the effects of treatment on (i) sward height (cm) (ii) number and height of Molinia tussocks. A Tukey post-hoc test was used to test significant pair-wise comparisons following ANOVA tests. A two-sample t-test was used to compare heather condition in Salt plots to No-salt plots. Kruskal-Wallis non-parametric ANOVA was used to test for differences between treatments (Salt, No-salt, Control) for (i) bare ground (\%), (ii) Molinia cover (\%), and (iii) number of heather seedlings. A Nemenyi, post-hoc test was used to test significant pair-wise comparisons following Kruskal-Wallis tests. Spearman's rank coefficient $\left(r_{s}\right)$ was used to test the relationship between sward height and distance from the centre of plots.

\section{CONSEQUENCES}

Measurements of sward height and derived herbage mass before the introduction of salt blocks showed no significant differences $(p>0.05)$ between the plots allocated to treatments Salt and No-salt. Average sward height and herbage mass were $28.6 \mathrm{~cm}(\mathrm{SE} \pm 0.41)$ and $87.9 \mathrm{~g} / \mathrm{m}^{2}(\mathrm{SE} \pm 4.8)$, respectively. Compared with the Control plots, using salt blocks to attract ponies resulted in an 18fold increase in the number of heather seedlings and a $9 \%$ reduction in the percentage cover of Molinia.

Data collected in July 2019 showed significant differences between treatments. Treatment had a significant effect on sward height $\left(\mathrm{F}_{(2,933)}=73.71\right.$, $\mathrm{p}$ $<0.001)$. Post-hoc pair wise comparisons of treatments showed significant differences $(\mathrm{p}<$ $0.001)$ in mean sward height between all treatments (Figure 2). Analyses showed a significant positive relationship between sward height and increasing distance from the central marker posts on Salt $\left(r_{s}=\right.$ $0.495, \mathrm{p}<0.001)$ and No-salt $\left(r_{s}=0.392, \mathrm{p}<\right.$ $0.001)$ plots; the impact of pony activity being greatest nearest to the marker posts.

Average cover of Molinia differed significantly $\left(\mathrm{H}_{(2,621)}=67.16, \mathrm{p}<0.001\right)$ between Salt, No-salt and Control plots, $83 \%, 88 \%$ and $92 \%$, respectively, differences between pairs were all significant at $\mathrm{p}<$ 0.001 . A weak significant positive correlation in $\%$ cover of Molina occurred with distance from the centre of plots $\left(r_{s}=0.213, \mathrm{p}<0.001\right)$. The average height of Molinia tussocks was significantly different $\left(\mathrm{F}_{(2,879)}=25.89, \mathrm{p}<0.001\right)$ between Salt $(13.9 \mathrm{~cm})$ and Control $(17.5 \mathrm{~cm})$ plots $\mathrm{p}<0.001)$, and No-salt $(14.3 \mathrm{~cm})$ and Control plots $(\mathrm{p}<0.001)$ but no significant difference occurred between Salt and No-salt plots $(\mathrm{p}>0.05)$,. However, treatment had no significant effect $(\mathrm{p}>0.05)$ on the number of Molinia tussocks (Salt plots $\overline{\mathrm{x}}=11.8$, No-salt plots $\overline{\mathrm{x}}$ $=11.9$, Control plots $\overline{\mathrm{x}}=12.8$ ).

Average occurrence of bare ground differed significantly $\left(\mathrm{H}_{(2,621)}=119 \mathrm{p}<0.001\right)$ between treatments. Significant differences occurred between Salt $(7.8 \%)$, and Control $(0.3 \%)$ plots $(\mathrm{p}<0.001)$, No-salt $(5 \%)$ and Control plots $(\mathrm{p}<0.001)$, and Salt and No-salt plots $(\mathrm{p}<0.05)$. A significant weak negative correlation in $\%$ bare ground occurred with the distance from the centre of the Salt plots $\left(r_{s}=\right.$ $0.230, \mathrm{p}<0.001)$.

There were significant differences in the number of heather seedlings between treatments $\left(\mathrm{H}_{(2,10)}=7.91, \mathrm{p} \leq 0.01\right)$; significantly more heather seedlings were recorded in the Salt $12.6(\mathrm{SE} \pm 1.5)$ compared with the Control 0.67 (SE \pm 0.4$)$ plots ( $p$ $<0.05)$. There were no significant differences $(\mathrm{p}>$ 0.05 ) between pair wise comparisons of No-salt 5.2 $(\mathrm{SE} \pm 2.6))$ and Control plots and Salt and No-salt plots (Figure 3). Figure 4 shows for the Salt plots, the greatest numbers of heather seedlings were

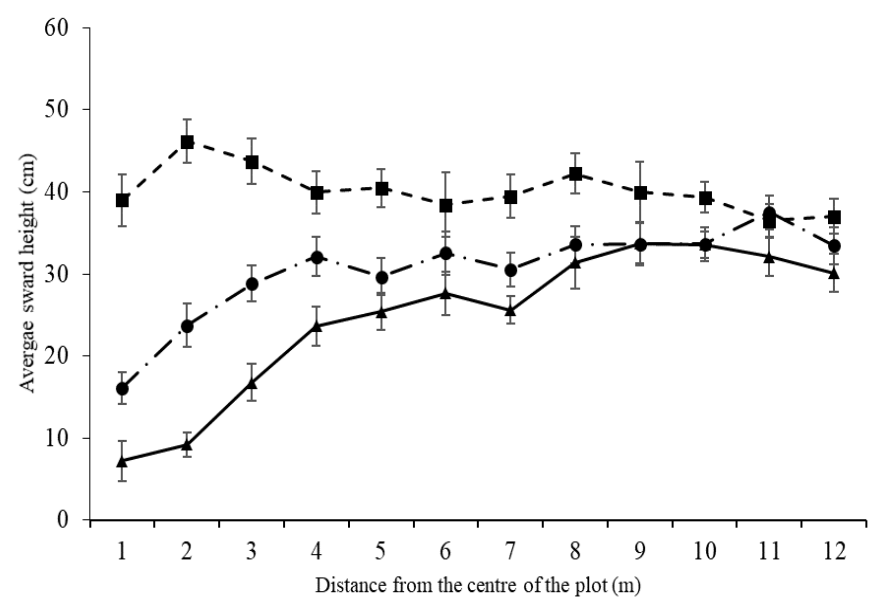

Figure 2. Changes in average sward surface height $(\mathrm{cm})$ with increasing distance from the plot centre $(1-12 \mathrm{~m})$ in year 3 (2019): Salt, $(\boldsymbol{\Lambda}, \mathrm{n}=30)$, No-salt $(\mathbf{O}, \mathrm{n}=30)$ and Control plots $(\mathbf{\square}, \mathrm{n}=18)$. Bars \pm standard errors. 
found at 2-4 $\mathrm{m}$ from the centre post. No seedlings were found at distance of 2-4 and $10 \mathrm{~m}$ in the Nosalt plots. No seedlings were found at 1-3 and 5-10 $\mathrm{m}$ in the Control plots. No heather seedlings were found at a distance of $12 \mathrm{~m}$ in any plots.

There was a significant difference $\left(\mathrm{t}_{(8)}=2.4, \mathrm{p}=\right.$ 0.042) in the condition of the mature heather plants on the Salt and No-salt plots, with $79 \%$ and $43 \%$ of plants, respectively, appearing to be in a healthy condition, with green leaves.

No quantitative measure was made of pony location. However, during regular site visits ponies were observed to be present and grazed for longer on the Salt plots (Figure 5).

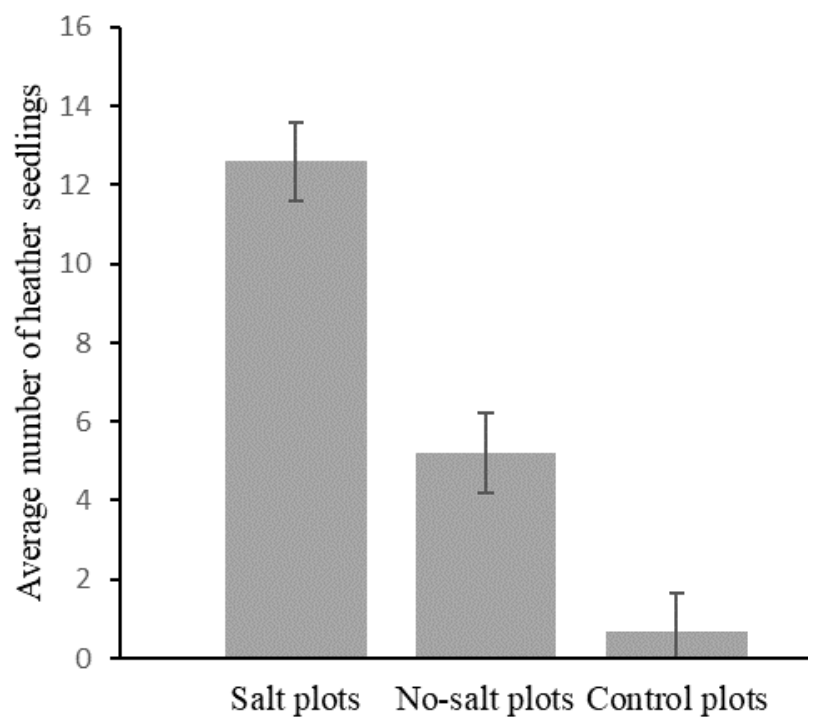

Figure 3. Average total numbers of new heather seedlings found in Salt plots $(\mathrm{n}=5)$, No-salt plots $(n=5)$ and Control plots $(n=3)$, with standard error bars. Values show the totals in $48\left(0.25 \mathrm{~m}^{2}\right)$ quadrats ( 8 distances along 6 radii) per sample plot, giving a total sampled area per plot of $12 \mathrm{~m}^{2}$.

\section{DISCUSSION}

The first aim of the experiment was to establish a suitable methodology for attracting ponies to graze selected Molinia-dominated areas. The findings from this study suggest that salt blocks can be used to attract Dartmoor ponies to graze selected areas without the need for fencing. The heft, the place where ponies habitually grazed, was altered by attracting them away to areas of ungrazed Moliniadominated moorland.

The marking of the No-salt plots with wooden posts had unintended, but interesting consequences. It became apparent after the first summer season that the posts were attracting ponies to the No-salt plots. Ponies were observed moving between Salt and Nosalt plots, foraging more or less continuously and occasionally rubbing on the marker posts. However, the ponies only congregated in numbers when they found a salt block. It appeared that, at a distance, they were unable to discriminate between Salt and Nosalt plot marker posts. Nevertheless, by spending just a short time at the No-salt posts, they caused a change in vegetation structure and composition, albeit less than on the Salt plots. Compared with the Control plots, their investigative behaviour around posts on No-salt plots led to significant reductions in sward height and Molinia cover and increases in bare ground, as shown in Figure 5.

These findings suggest that where this methodology is used, it may be sufficient to move the salt blocks in rotation around a series of locations to provide moorland management at an ecologically meaningful scale. By installing several posts and frequently changing the position of the salt blocks, sufficient disturbance due to grazing and trampling by the ponies can be achieved and the damaging effects from severe disturbance avoided.

The second aim of the experiment was to determine if Dartmoor ponies could be used in

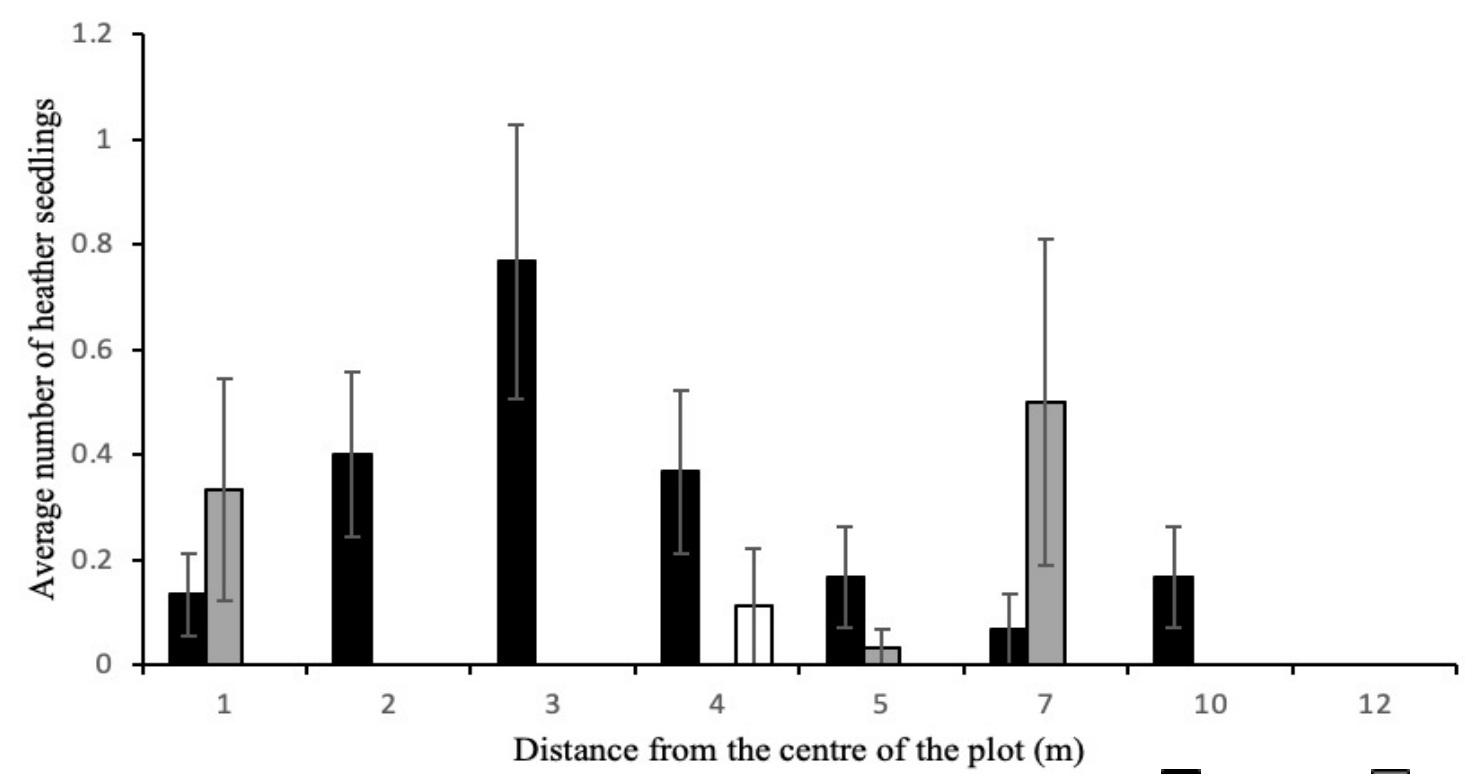

Figure 4. Average number of heather seedlings/quadrat $\left(0.25 \mathrm{~m}^{2}\right)$ in Salt, $(\square)$, No-salt $(\square)$ and Control plots ( $\square$ ), at distances of 1-12 m distant from the centre of the plots in year 3 (2019). Bars indicate standard errors. Salt plots $(n=30)$, No-salt plots $(n=30)$ and Control plots $(n=18)$. 
moorland conservation management to control Molinia and enable the regeneration of heather.

Previous research has shown that to successfully establish heather in Molinia-dominated moorland requires firstly the reduction of Molinia cover and secondly the disturbance of the soil surface to create a seed bed (Milligan et al. 2004). In this study the provision of salt blocks led to a significant reduction in sward height (Figure 2), an increase in bare ground and a reduction in the \% cover of Molinia, compared with No-salt and Control plots.

Heather seeds can accumulate in moorland soils - usually distributed more or less evenly within the top $5 \mathrm{~cm}$ of soil - and remain viable for many decades until exposed to light (Legg et al. 1992). Due to their small size and limited energy reserves, in undisturbed soils only those seeds close to the soil surface are likely to establish successfully (Mitchell et al. 2008). Dense tussocks of senescent Molinia create a cool, humid micro-environment, which supports dense communities of bryophytes within the inter-tussock spaces. As a consequence, heather seeds may be supressed due to lack of light even between the tussocks of Molinia. Our results suggest that by reducing Molinia cover and disturbing the upper soil layers, our treatment may have allowed the germination of previously buried seeds.

In this study, increases in the germination and establishment of heather seedlings from the seed bank became apparent two summers after the introduction of salt blocks. The number of heather seedlings was fewer in pre-treatment plots in 2017 , increasing to an average of 5.0 seedlings/treatment plot in 2018 and 12.6 seedlings/plot in 2019. The largest numbers of heather seedlings occurred 2-4 m from the salt blocks (Figure 4) where intermediate levels of grazing and trampling caused reductions in sward height and Molinia cover. Within $1 \mathrm{~m}$ of the salt blocks, levels of disturbance appeared to be excessive, resulting in loss of any developing seedlings.

An existing seedbank is essential for reestablishment of heather. The population of mature heather and other dwarf shrub plants was sparse and senescing on the site but may have contributed to seed rain to augment the supply of seeds in the soil. In addition to creating the conditions suitable for germination, where there is no existing seed bank or seed rain, seeds would need to be added. There was also some evidence that grazing may have improved the condition of the mature heather plants within the Salt plots, with a lower percentage of plants judged as being in a poor condition in 2019, compared to the No-salt plots. Early indications suggest that grazing of the Molinia by the ponies has increased the rate of recovery of the heathland vegetation components of the SSSI.

Equines, unlike cattle and sheep, are hindgut fermenters, requiring continual intake of feedstuffs, and they have a high digesta passage rate and relatively high seed viability in their dung. In addition, the Dartmoor pony maintains good condition on moorland grasses and is adapted to overwintering conditions in the uplands. These factors, combined with the disturbance created by their hoof fall, make this breed highly suitable for conservation grazing on moorland and upland heath.

This research provides evidence of the intrinsic value of Dartmoor or other native pony breeds in conservation-grazing schemes. The recommendations of this research are that nativepony grazing should be considered as a land management option for upland heath and moorland, where the conservation objectives are to reduce Molinia and re-establish heather. It is hoped that this research will assist Defra and Natural England in the planning of the UK Government's new Environmental Land Management scheme. However, support under that scheme should take into account that salt blocks on their own may not be enough to reduce Molinia sward height and dominance in the long term.

As of September 2019, no more salt blocks were placed on the Salt plots. In the future we will continue to monitor pony grazing in the experimental plots to see if there has been a permanent change in the hefting behaviour of the ponies and verify if the experiment produces a sustained improvement in heathland condition.

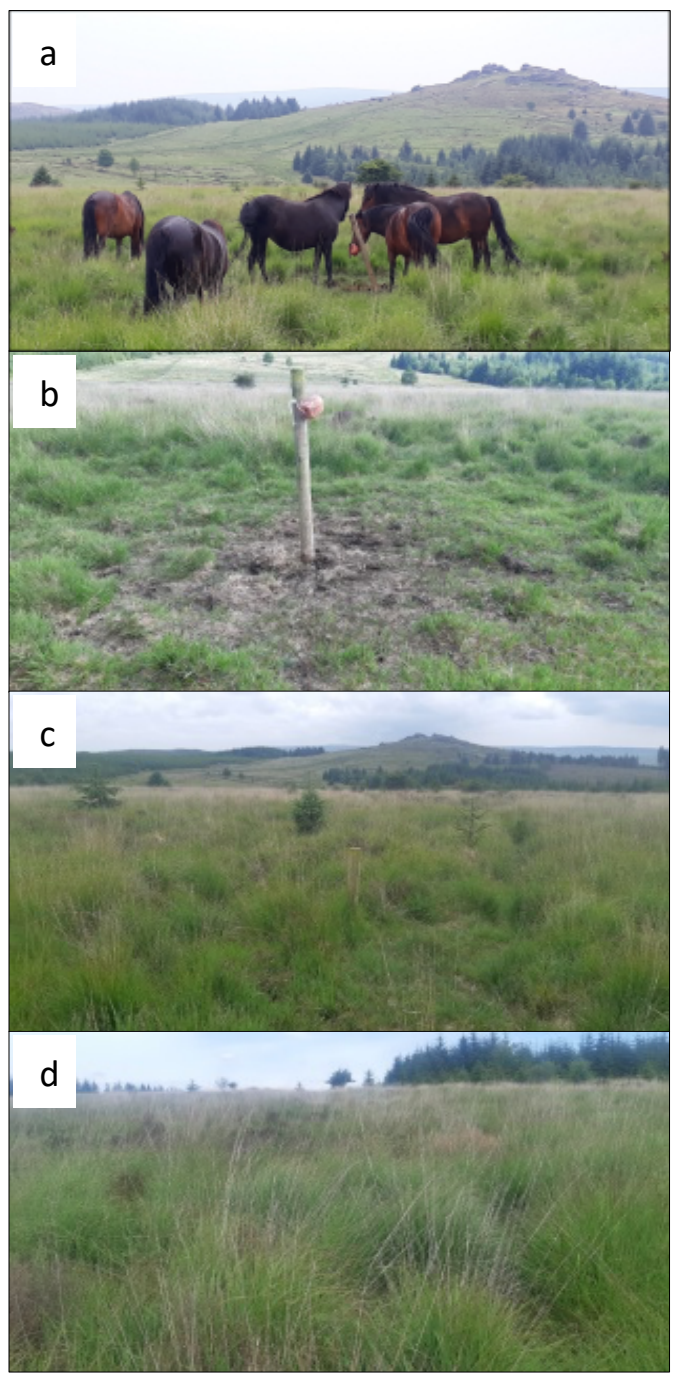

Figure 5. (a) ponies grazing near salt blocks, and their impact on (b) Salt, (c) No-salt and

(d) Control plots. 


\section{ACKNOWLEDGEMENTS}

The authors wish to thank Dru Butterfield and Clare Stanton of the Dartmoor Pony Heritage Trust for overseeing the management of the ponies and providing financial support for the field researchers. The authors also acknowledge the work conducted by Rory Holness and Alex Bridel (University of Plymouth) in providing valuable baseline survey data.

\section{REFERENCES}

Aldezabal A., Mandaluniz N. \& Laskurain N. (2013) Gorse (Ulex spp.) use by ponies in winter: Is the spatial pattern of browsing independent of the neighbouring vegetation? Grass and Forage Science, 68, 49-58, doi.org/10.1111/j.13652494.2012.00865.x.

Celaya R., Ferreira L., Garcia U., Garcia R. \& Osoro K. (2011) Diet selection and performance of cattle and horses grazing in heathlands. Animal, 5 , 1467-1473. doi.org/10.1017/S1751731111000449

Chambers F.M., Mauquoy D. \& Todd P. (1999) Recent rise to dominance of Molinia caerulea in environmentally sensitive areas: new perspectives from paleoecological data. Journal of Applied Ecology, 36, 719-733. doi.org/10.1046/j.1365-2664.1999.00435.x

Critchley C.N., Mitchell R., Rose R., Griffiths B., Jackson E., Scott H. \& Davies O. (2013) Reestablishment of Calluna vulgaris (L.) Hull in an eight-year grazing experiment on upland acid grassland. Journal of Nature Conservation, 21, 22-30 doi.org/10.1016/j.jnc.2012.08.005.

Dicks, L.V., Ashpole, J.E., Dänhardt, J., James, K., Jönsson, A., Randall, N., Showler, D.A., Smith, R.K., Turpie, S., Williams, D.R. \& Sutherland, W.J. (2020) Farmland Conservation. Pages 283321 in: W.J. Sutherland, L.V. Dicks, S.O. Petrovan \& R.K. Smith (eds) What Works in Conservation 2020. Open Book Publishers, Cambridge, UK.

Fraser M., Stanley C.R. \& Hegarty M. (2019) Recognising the potential role of native ponies in conservation management. Biological Conservation, 235, 112-118. doi.org/10.1016/j.biocon.2019.04.014

JNCC (2008). UK Biodiversity Action Plan Priority habitat descriptions, upland heathland. https:/data.jncc.gov.uk/data/1be8bec3-04374758-adc8-ac866d4e0769/UKBAPBAPHabitats-61-UplandHeathland.pdf.

Kaspari, M. (2020) The seventh macronutrient: how sodium shortfall ramifies through populations, food webs and ecosystems. Ecology Letters, 23, 1153-1168. https://doi.org/10.1111/ele.13517.

Legg C.J., Maltby E. \& Proctor M.C.F. (1992) The ecology of severe moorland fire on the North York Moors: seed distribution and seedling establishment of Calluna vulgaris. Journal of Ecology, 80, 737-752 doi.org/10.2307/2260863.
López López, C., Celaya, R., Ferreira, L.M.M., García, U., Rodrigues, M.A.M. and Osoro, K. (2019). Comparative foraging behaviour and performance between cattle and horses grazing in heathlands with different proportions of improved pasture area. Journal of Applied Animal Research, 47(1), 377-385 doi.org/10.1080/09712119.2019.1649679

Murphy T.R., Hanley M.E., Ellis J.S. \& Lunt P.H. (2019) Deviation between projected and observed precipitation trends greater with altitude. Climate Research, 79, 77-89. doi.org/10.3354/cr01583

Marrs R.H., Phillips J.D., Todd P.A., Ghorbani J. \& Le Duc M. (2004) Control of Molinia caerulea on upland Moors. Journal of Applied Ecology, 41, 398-411. doi.org/10.1111/j.00218901.2004.00901.x

Milligan A., Putwain P., Cox E., Ghorbani J., Le Duc M. \& Marrs R. (2004) Developing an integrated land management strategy for the restoration of moorland vegetation on Molinia caeruleadominated vegetation for conservation purposes in upland Britain. Biological Conservation, 119, 371-385 dx.doi.org/10.1016/j.biocon.2003.12.002.

Mitchell R., Rose R. \& Palmer S. (2008) Restoration of Calluna vulgaris on grass-dominated moorlands: The importance of disturbance, grazing and seeding. Biological Conservation, 141, 2100-2111. dx.doi.org/10.1016/j.biocon.2008.06.006

Putman R.J., Pratt R.M., Ekins J.R. \& Edwards P. (1987) Food and Feeding Behaviour of Cattle and Ponies in the New Forest, Hampshire. Journal of Applied Ecology. 24, 369-380. $10.2307 / 2403881$.

Ross S., Adamson H. \& Moon A. (2003) Evaluating management techniques for controlling Molinia caerulea and enhancing Calluna vulgaris on upland wet heathland in northern England. UK. Agriculture, Ecosystems and Environment, 97, 39-49. dx.doi.org/10.1016/S01678809(03)00141-5.

Sala O.E., Chapin F.S., Armesto J.J., Berlow E., Bloomfield J., Dirzo R., Huber-Sanwald E., Huenneke L.F., Jackson R.B., Kinzig A., Leemans R., Lodge D.M., Mooney H.A., Oesterheld M., Poff N.L., Sykes M.T., Walker B.H., Walker M. \& Wall D.H. (2000) Global biodiversity scenarios for the year 2100 . Science, 287, 1770-1774. doi.org/10.1126/science.287.5459.1770.

Yallop A.R., Thacker J.I., Thomas G., Stephens M., Clutterbuck B., Brewer T. \& Sannier C.A.D. (2006) The extent and intensity of management burning in the English uplands. Journal of Applied Ecology, 43, 1138-1148. doi.org/10.1111/j.1365-2664.2006.01222.x 